\title{
Media Pembelajaran Berbantuan Komputer: Penggunaan dan Pengaruhnya Terhadap Pemahaman Konsep Matematis Siswa SMP
}

\author{
Meilani Safitri1 ${ }^{1}$ Tria Gustiningsi² ${ }^{2}$ Lis Amalia ${ }^{3}$ \\ meilani_safitri@unisti.ac.id
}

\begin{abstract}
The aim of this research is to develop mathematics learning media for student in class VII of junior high school. After going through the stages of developing a valid and practical instructional media, the instructional media is used to see whether there is an influence of its use on the understanding of mathematical concepts of grade VII junior high school students. The method used in this study is a mix method between development and experimentation. The results of this study are valid and practical learning media. While the effect on understanding students' mathematical concepts is significant. Thus, the initial hypothesis was accepted.
\end{abstract}

Keywords: Learning Media, Concept Understanding, Computer Aided

\footnotetext{
1 Universitas Sjakhyakirti

2 Universitas Sjakhyakirti

3 Universitas Sjakhyakirti
} 


\section{PENDAHULUAN}

$\mathrm{M}$ atematika merupakan bidang ilmu pengetahuan yang abstak dan kompleks sehingga untuk memahaminya diperlukan penjelasan yang sederhana dan praktis. Konsep-konsep matematika yang abstrak ini masih sulit dipahami oleh siswa di sekolah menengah pertama (SMP) berdasarkan hasil penelitian terdahulu tingkat pemahaman konsep matematis siswa masih dalam kategori rendah khususnya pada materi geometri. Menurut Ompussungu (2014), pemahaman konsep matematika dapat diartikan dalam suatu proses pengamatan yang tidak langsung dalam menyerap pengertian dari konsep atau teori yang akan dipahami dan mempertunjukkan kemampuannya di dalam menerapkan konsep/ teori yang akan dipahami pada keadaan atau situasi permasalahan yang lebih luas. Salah satu dari lima tujuan pembelajaran matematika yaitu memahami konsep matematika. Namun pada kenyataannya tingkat pemahaman konsep matematis siswa masih rendah, padahal keberhasilan proses belajar dan mengajar selain dipengaruhi oleh metode mengajar juga dipengaruhi oleh tingkat pemahaman konsep siswa. Siswa dengan pemahaman konsep yang baik dipercaya akan memiliki hasil belajar yang baik pula. (Safitri, 2017). Untuk meningkatkan pemahaman konsep matematis siswa, pendidik dituntut agar memiliki strategi dalam mengajarkan konsep matematika yang abstrak dan kompleks sehingga mampu memberikan pemahaman kepada peserta didik. Pendidik diharapkan mampu menerapkan berbagai metode belajar yang tidak hanya menarik dan berbeda tapi juga efektif dan efisien. Sehingga dengan demikian diharapkan siswa yang tadinya kurang dalam memahami konsep matematika menjadi lebih paham.

Annajmi (2016) mengatakan bahwa pemahaman konsep memiliki peran yang penting dalam pembelajaran matematika, sehingga pemahaman konsep merupakan suatu kemampuan yang perlu diperhatikan. Namun kenyataan yang ditemukan, kemampuan pemahaman konsep yang dimiliki siswa saat ini masih belum menunjukkan adanya kemampuan pemahaman konsep yang baik. Rendahnya kemampuan pemahaman konsep siswa terhadap matematika terlihat dari cara siswa dalam menyelesaikan soal-soal yang diberikan. Siswa kesulitan menyelesaikan soal-soal yang berbeda dari contoh-contoh yang diberikan guru. Siswa hanya berfokus pada contoh-contoh yang telah diberikan guru. Siswa masih belum dapat mengungkapkan kembali dengan lengkap konsep yang telah dipelajari, begitu juga menggunakan konsep dalam pemecahan masalah, masih banyak ditemukan siswa kesulitan dalam menjawab soal-soal yang diberikan guru, dikarenakan siswa tidak paham menggunakan konsep yang mana untuk pemecahan masalah tersebut.

Rendahnya kemampuan pemahaman konsep siswa terhadap matematika terlihat dari cara siswa dalam menyelesaikan soal-soal yang diberikan guru. Siswa masih belum dapat mengungkapkan kembali dengan lengkap konsep yang telah dipelajari, begitu juga menggunakan konsep dalam pemecahan masalah, masih banyak ditemukan siswa kesulitan dalam menjawab soal-soal yang diberikan guru, dikarenakan siswa tidak paham menggunakan konsep yang mana untuk pemecahan masalah tersebut. Pembelajaran yang laksanakan di dalam kelas lebih kepada latihan soal-soal dan diskusi yang berpusat pada guru, belum memaksimalkan keaktifan siswa dalam proses pembelajaran. Selain itu, penyebab kurangnya pemahaman siswa terhadap suatu konsep adalah pembelajaran yang terpusat pada guru (Richi \& Muchtar, 2017).

Sementara itu, mengingat pada rancangan kurikulum nasional yang menyebutkan bahwa dalam struktur kurikulum SMP komputer bukanlah mata pelajaran melainkan sarana belajar pada semua mata pelajaran, maka pendidik dituntut untuk melibatkan komputer dalam proses belajar mengajar. Namun pada kenyataannya masih banyak pendidik yang belum menggunakan komputer sebagai sarana ataupun media dalam pembelajaran dan yang menjadi salah satu penyebab hal ini terjadi adalah karena banyaknya guru yang belum mampu membuat media pembelajaran berbantuan komputer bahkan ada saja yang tidak mengenal komputer sama sekali. 
Darminto (2011) mengatakan bahwa pembelajaran matematika berbasis komputer merupakan pembelajaran yang berlandaskan pada konsep Computer-Based Instruction (CBI) maupun Computer Assisted Instruction (CAI). Pada awalnya CBI atau CAI dikembangkan berdasarkan teori perilaku dan pembelajaran terprogram, namun sekarang telah dikembangkan berdasarkan teori kognitif sehingga saat ini para programming dan guru/dosen matematika telah berkolaborasi untuk membuat beberapa program aplikasi multimedia interaktif yang didasarkan pada tingkat kemampuan dan kesiapan belajar anak.

Penggunaan komputer dalam pembelajaran matematika yang dilaksanakan di Jepang dapat meningkatkan efektivitas pembelajaran karena komputer dapat membantu visualisasi bangun-bangun geometri, menghitung operasi-operasi bilangan dengan cepat, dan dapat menyelesaikan beberapa persoalan matematika (Fumiyuki, 2000). Setiawan (2005) menyatakan bahwa pembelajaran berbasis komputer dapat meningkatkan pemahaman konsep, kompetensi tertentu dan ketrampilan berpikir kritis. Chambers (2008) berpendapat bahwa penggunaan teknologi komputer dalam pembelajaran matematika dapat memberikan begitu banyak fungsi-fungsi yang berbeda. Beberapa fungsi komputer secara langsung membantu anak dalam belajar matematika, fungsi lainnya membantu anak tidak secara langsung dengan memungkinkan anak mengakses data dalam jumlah besar atau memberikan analisis yang cepat terhadap data tersebut yang bila dibandingkan tanpa menggunakan komputer akan memakan waktu yang sangat lama, fungsi ketiga dari penggunaan teknologi komputer adalah meningkatkan kemampuan anak dibidang teknologi informasi dan komunikasi seperti kemampuan anak menggunakan komputer untuk mengorganisasikan, menganalisis, dan menampilkan informasi.

Lebih rinci Chambers memaparkan keuntungan penggunaan komputer di kelas: a. Memberikan kontribusi pada kemajuan penguasaan teknologi informasi dan komunikasi. b. Memberikan umpan balik yang yang cepat terhadap jawaban dan ide anak, berbeda dengan ketika anak harus menunggu lama umpan balik dari guru. c. Meningkatkan kecepatan pembelajaran dengan memungkinkan pertukaran tampilan yang cepat dan memberikan respon yang cepat terhadap banyak pertanyaan. $\mathrm{d}$. Meningkatkan kualitas tampilan, sehingga anak dapat melihat diagram yang lebih sempurna bila dibandingkan buatan tangan yang akurasinya lebih rendah. e. Memungkinkan anak untuk menggali ideide yang berbeda untuk melihat apa yang terjadi. Misalnya melihat pengaruh nilai konstanta yang berbeda pada grafik aljabar. f. Menggali pola-pola matematika dan hubungannya g. Mengolah, mengurutkan dan menganalisis data secara cepat dan mudah. $h$. Memfasilitasi pengerjaan data yang besar termasuk data real. Menurut Chee \& Wong (2003), untuk mengetahui kelayakan media pembelajaran dapat ditinjau dari: a. Appropriatness dimana materi harus sesuai dengan karakteristik dan kurikulum di perguruan tinggi atau sekolah setempat. b. Accuracy, Currency, and Clarity yaitu materinya akurat, up-to-date, jelas dalam menjelaskan konsep, valid, dan tidak membias, dan sesuai dengan tingkat kesulitan siswa. c. Screen Presentation and Design yaitu tampilan layarnya menggunakan kombinasi warna, gambar dan tulisan yang padu dan serasi. Adapun tujuan dalam penelitian ini adalah untuk mengetahui adakah pengaruh yang signifikan dalam pengembangan dan penggunaan media pembelajaran berbantuan komputer tehadap kemampuan pemahaman konsep matematis siswa.

\section{METODE PENELITIAN}

Penelitian ini dilaksanakan di SMP Negeri 20 yang berlokasi di Kecamatan Seberang Ulu Plaju Palembang. Sampel yang digunakan sejumlah 31 siswa kelas VII; 31 siswa di kelas kontrol dan 31 siswa di kelas eksperimen. Data yang diperoleh adalah data kualitatif dan kuantitatif. Data kualitatif berupa data yang diperoleh dari hasil observasi terhadap aktivitas belajar siswa dengan menggunakan media pembelajaran berbantuan komputer dan yang menggunakan metode biasa. 
Penelitian ini menggunakan metode eksperimen yaitu Quasi-Experimental karena subjek tidak dikelompokkan secara acak, tetapi diterima apa adanya. Quasi-eksperimental design yang digunakan adalah Posttest-Only Control Group Design dengan Pola:

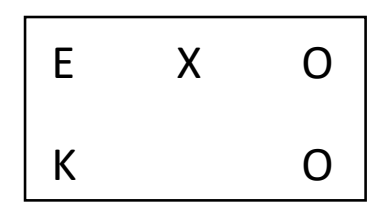

Gambar 1. Pola penelitian eksperimen post test only

Perlakuan (treatment) $(\mathrm{X})$ yaitu media pembelajaran berbantuan komputer (menggunakan aplikasi macromedia flash), kelompok yang diberi perlakuan disebut kelompok eksperimen (E) yang diberi perlakuan media pembelajaran berbantuan komputer (menggunakan aplikasi macromedia flash) dan kelompok yang tidak di beri perlakuan disebut kelompok kontrol $(K)$. (O) adalah postest untuk melihat kemampuan pemahaman konsep siswa dari kelas eksperimen dan kelas kontrol.

\section{HASIL DAN PEMBAHASAN}

Sebelum pelaksanaan penelitian, terlebih dahulu dilakukan wawancara kepada guru matematika yang mengajar di kelas control dan kelas eksperimen. Tujuannya untuk mengetahui data siswa seperti jumlah, daftar hadir, dan informasi tentang sejauh mana pelajran matematika di kelas tersebut serta metode atau model pembelajaran apa yang pernah digunakan.

Tahap pelaksanaan, peneliti melaksanakan kegiatan pembelajaran matematika dengan materi segitiga di dua kelas berbeda yaitu kelas VII.1 sebagai kelas eksperimen dan kelas VII.6 sebagai kelas control. Pembelajaran di kelas VII.1 menggunakan media pembelajaran berbantuan computer, dilakukan dalam dua kali tatap muka dengan rincian satu kali tatap muka adalah $2 \times 40$ menit dan satu kali post tes di hari ke tiga. Selama pembelajaran siswa dibagi menjadi delapan kelompok heterogen. Siswa diarahkan untuk belajar mandiri menggunakan media pembelajaran berbantuan komputer yang telah disiapkan.

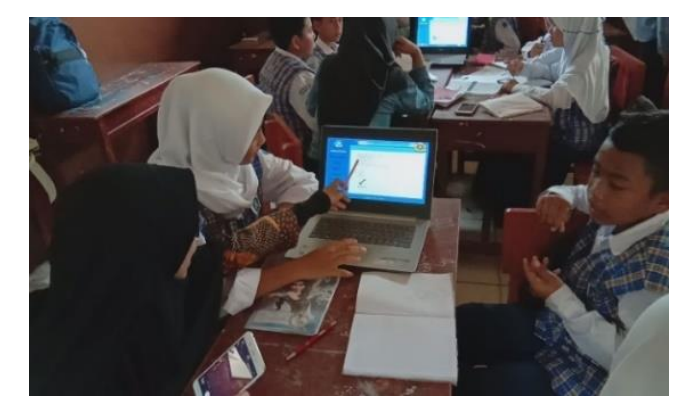

Gambar 2. Pembelajaran menggunakan media berbantuan komputer di kelas VII.1

Pada pertemuan terakhir dilakukan post tes untuk mengetahui kemampuan pemahaman konsep matematis siswa setelah dilakukan pembelajaran menggunakan media berbantuan komputer. Adapun jumlah soal lima butir dengan bentuk soal uraian. 


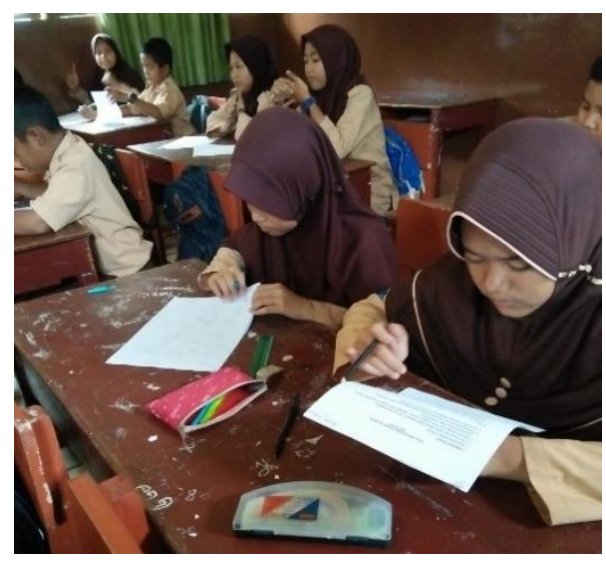

Gambar 3. Siswa sedang mengerjakan soal post tes

Setelah dilakukan tes akhir, peneliti mengoreksi lembar jawaban siswa dan menganalisis hasilnya untuk mengetahui tingkat pemahaman konsep matematis di kelas eksperimen. Uji lapangan dilakukan setelah pelaksanaan pembelajaran dengan metode konvensional dan juga dilakukan observasi. Hal ini bertujuan untuk melihat hasil dari pembelajaran apakah sudah mencapai target pembelajaran yang diinginkan atau belum. Dari hasil uji lapangan yang dilakukan dikelas kontrol terdapat 25 orang siswa yang hadir dari 31 siswa, ternyata tidak seorangpun siswa yang memiliki kategori tingkat kemampuan pemahaman konsep kategori baik sekali maupun kategoti baik. Hanya 1 siswa yang masing-masing memenuhi kategori cukup dan kurang. Sementara terdapat 23 siswa yang masuk kategori sangat kurang. Dari hasil ini maka dapat dilihat bahwa masih banyak siswa yang belum bisa mengindentifikasi informasi yang diketahui, menyelidiki dan mengembangkan rumus serta mencari solusi sampai menarik kesimpulan dari permasalahan yang ada. Nyatanya model pembelajaran konvensional belum bisa memperbaiki kemampuan pemahaman konsep siswa dalam belajar.

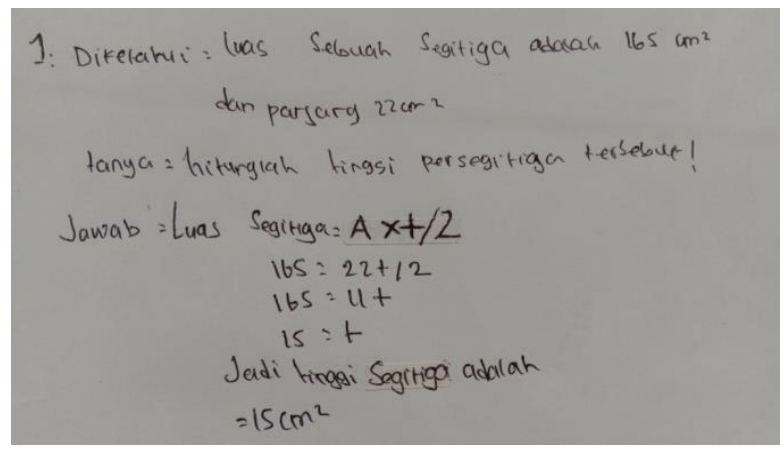

Gambar 4. Contoh jawaban siswa untuk soal no.1

Pada gambar 4 menunjukkan jawaban benar dari soal no 1 dimana siswa memahami soal dengan baik dan mengerti tujuan akhir yang diinginkan soal. Terlihat ia mampu menuliskan informasi yang didapat dari soal dengan tepat dan menuliskan rumus luas segitiga. Pada tahap selanjutnya siswa bisa memasukkan nilai-nilai dari informasi yang diberikan soal ke dalam rumus segitiga dengan tepat. Selain itu ia mampu melakukan perhitungan matematika sesuai dengan aturan matematika yang benar, sehingga didapatlah nilai tinggi dari segitiga. Namun ada sedikit kesalahan kecil yang dilakukan yaitu saat penulisan rumus segitiga dimana cara penulisan tanda bagi di tuliskan dengan garis miring yang sebenarnya tidak sesuai dengan kaidah penulisan yang benar di dalam matematika. Hal ini dikawatirkan akan berdampak pada proses perhitungan. Namun karena dia memiliki landasan 
pemahaman dan ketelitian yang baik maka hal tidak berefek besar. Selain itu juga kesalahan kedua yang dilakukan adalah pada penulisan hasil akhir dimana siswa menuliskan nilai tinggi segitiga dalam satuan $\mathrm{cm}^{2}$ yang seharusnya dalam satuan panjang yaitu $\mathrm{cm}$.

Hipotesis dalam penelitian ini adalah "Ada pengaruh media pembelajaran berbantuan komputer dengan kemampuan pemahaman konsep matematis siswa" dengan kriteria hipotesisnya adalah:

$\mathrm{H}_{0}: \mu_{1} \leq \mu_{2}$ : Tidak ada pengaruh media pembelajaran berbantuan komputer dengan kemampuan pemahaman konsep matematis siswa.

$\mathrm{H}_{\mathrm{a}}: \mu 1>\mu 2$ : Ada pengaruh media pembelajaran berbantuan komputer dengan kemampuan pemahaman konsep matematis siswa.

Untuk menguji hipotesis di atas, peneliti menggunakan rumus uji-t dengan kriteria:

$\mathrm{H}_{0}$ diterima jika nilai $\mathrm{t}$ hitung $\leq \mathrm{t}$ tabel

$\mathrm{H}_{0}$ ditolak jika t hitung $>\mathrm{t}$ tabel

Tabel 1. Hasil Uji Hipotesis

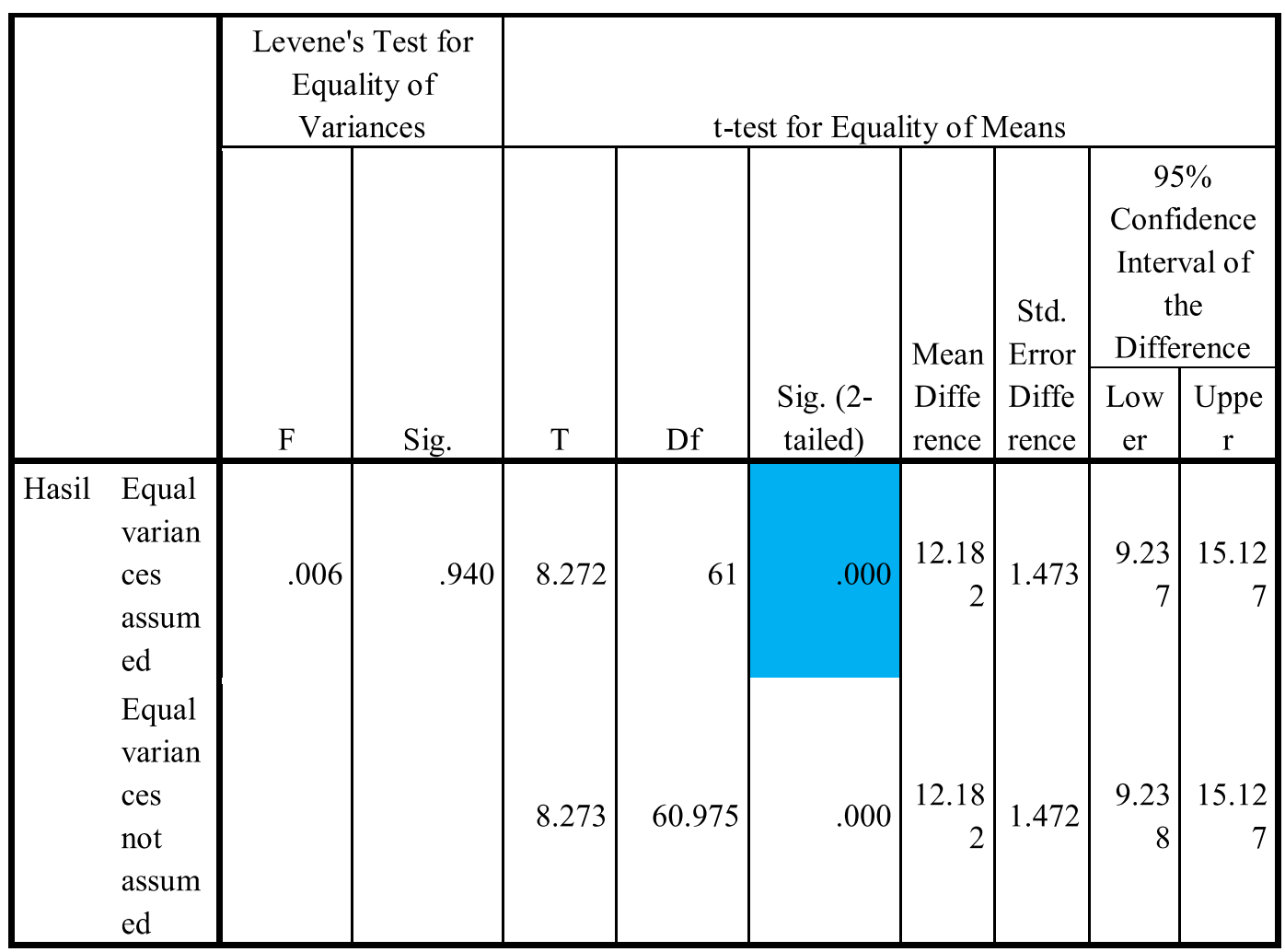

Berdasarkan hasil perhitungan pada tabel 1 , diperoleh nilai sig. $(2-$ tailed $)=0,000$. Menurut Siregar (2013) hubungan antara sig. (2- tailed) dan sig. (1- tailed) adalah: sig. (1- tailed) = sig. $(2-$ tailed) maka sig. (1- tailed $)=0,000$. Karena sig. $(1-$ tailed $)<0,05$ berdasarkan kriteria pengujian hipotesis maka $\mathrm{H}_{0}$ ditolak berarti $\mathrm{Ha}_{a}$ diterima dan dapat disimpulkan bahwa "Ada pengaruh media pembelajaran berbantuan komputer dengan kemampuan pemahaman konsep matematis siswa".

Dari 31 orang siswa di kelas eksperimen, ada 18 orang siswa yang memiliki kemampuan pemahaman konsep dengan kategori sangat baik, 4 orang termasuk kategori baik, 5 orang termasuk 
dalam kategori cukup, dan 4 orang termasuk dalam kategori kurang baik. Hal ini dapat dilihat pada tabel 2.

Tabel 2. Jumlah siswa yang memenuhi kategori kemampuan pemahaman konsep pada kelas eksperimen

\begin{tabular}{cc}
\hline Kategori & Jumlah siswa \\
\hline Sangat Baik (SB) & 18 \\
\hline Baik (B) & 4 \\
\hline Cukup (C) & 5 \\
\hline Kurang Baik (KB) & 4 \\
\hline Tidak Baik (TB) & 0 \\
\hline Total & 31
\end{tabular}

18 orang siswa yang memiliki kemampuan dengan kategori sangat baik, terlihat saat pelaksanaan pembelajaran siswa-siswa tersebut dapat mengilustrasikan pengetahuan awal, menyelidiki dan menghubungkan konsep awal dengan konsep baru yang akan ditemukan, menjelaskan masalah maupun solusi, dan menarik kesimpulan. Terlihat pada Gambar 2, siswa melakukan langkahlangkah kegiatan dan mencoba animasi yang tersedia dalam media pembelajaran berbantuan komputer tersebut.

Selama pelaksanaan pembelajaran, siswa mengikuti langkah-langkah dalam media pembelajaran, dimulai dari mengenal identitas segitiga, jenis-jenis segitiga, keliling segitiga, dan luas segitiga. Dengan adanya animasi dalam media pembelajaran, siswa menjadi lebih mengerti mengenai konsep segitiga tersebut, siswa memperhatikan animasi keliling segitiga sehingga menghasilkan rumus keliling segitiga yaitu sisi ditambah sisi ditambah sisi (sisi + sisi + sisi), begitupun animasi untuk menemukan rumus luas segitiga. Hal ini sangat membantu siswa memahami konsep segitiga tersebut. Pada saat mengerjakan latihan soal yang tersedia dalam media, siswa memenuhi indikator kemampuan pemahaman konsep dan menjawab soal dengan benar.

Selain itu, ada 4 orang siswa yang memiliki kemampuan pemahaman konsep dengan kategori baik. 4 orang siswa ini memenuhi tiga indikator kemampuan pemahaman konsep, tapi siswa tidak memenuhi indikator menjelaskan. Siswa tidak menjelaskan deskripsi masalah, tidak menjelaskan langkah-langkah pengerjaan, dan tidak menjelaskan solusi yang didapat.

Kemudian 5 orang siswa memiliki kemampuan pemahaman konsep dengan kategori cukup. 5 orang siswa ini terlihat pasif dan kesulitan mengoperasikan komputer, hal ini yang mempengaruhi siswa tidak maksimal dalam pembelajaran.

Ada 4 orang siswa yang memiliki kemampuan pemahaman konsep dengan kategori kurang baik. 4 orang ini kesulitan mengikuti pembelajaran dan kesulitan menjawab soal latihan yang disediakan dalam media pembelajaran karena kemampuan awal siswa mengenai operasi hitung perkalian dan pembagian sangat kurang. 
Pada kelas kontrol, dari 31 orang siswa di kelas ada 5 orang siswa yang memiliki kemampuan pemahaman konsep dengan kategori sangat baik, 12 orang dengan kategori baik, 12 orang dengan kategori cukup, dan 2 orang dengan kategori kurang baik.

Tabel 2. Jumlah siswa yang memenuhi kategori kemampuan pemahaman konsep pada kelas kontrol

\begin{tabular}{cc}
\hline Kategori & Jumlah siswa \\
\hline Sangat Baik (SB) & 5 \\
\hline Baik (B) & 12 \\
\hline Cukup (C) & 12 \\
\hline Kurang Baik (KB) & 2 \\
\hline Tidak Baik (TB) & 0 \\
\hline Total & 31
\end{tabular}

5 orang siswa yang memiliki kemampuan pemahaman konsep sangat baik, pada saat pembelajaran terlihat lebih aktif bertanya, memperhatikan dan merespon guru. Hal ini juga yang mempengaruhi siswa sehingga saat diberikan soal atau pertanyaan oleh guru, siswa mampu mengidentifikasi unsur-unsur yang diketahui, mencatat hal-hal yang diketahui, menyelidiki dan mencari solusi, menjelaskan, hingga menarik kesimpulan.

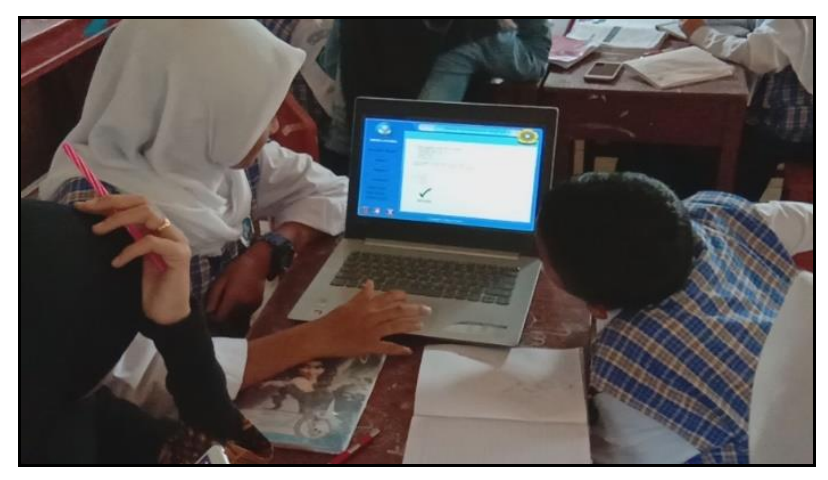

Gambar 5. Uji coba produk

12 orang siswa memiliki kemampuan pemahaman konsep dengan kategori baik. Pada saat pembelajaran berlangsung, siswa memperhatikan saat guru menjelaskan di depan kelas namun siswa tidak mampu menjelaskan dan menarik kesimpulan, sehingga ada indikator yang tidak terpenuhi. Kemudian, 12 orang lagi siswa yang memiliki kemampuan pemahaman konsep dengan kategori cukup. 12 orang ini mengikuti pembelajaran namun masih perlu dibimbing dan diarahkan oleh guru. Saat diberikan soal atau pertanyaan oleh guru, siswa tidak bisa menyelidiki dan menghubungkan konsep awal dengan konsep baru yang akan ditemukan, namun siswa mampu mengidentifikasi yang diketahui 
maupun yang ditanyakan dalam soal. Ada 2 orang siswa yang memiliki kemampuan pemahaman konsep dengan kategori kurang baik. Saat pembelajaran berlangsung, siswa tidak merespon dengan baik penjelasan dari guru. Saat diberikan pertanyaan atau soal oleh guru, siswa tidak bisa mengidentifikasi unsur yang diketahui maupun yang ditanyakan dalam soal, sehingga tidak bisa menyelesaikan dengan baik soal tersebut.

\section{KESIMPULAN}

Berdasarkan hasil penelitian dan analisis data di atas maka dapat disimpulkan bahwa "Ada pengaruh yang signifikan dalam pengembangan dan penggunaan media pembelajaran berbantuan komputer terhadap kemampuan pemahaman konsep matematis siswa".

\section{DAFTAR PUSTAKA}

Annajmi. (2016). Peningkatan pemahaman konsp matematik siswa smp melalui metode penemuan terbimbing berbantuan software geogebra. MES: Journal of Mathematics Education and Science, 2(1), 1-10. https://doi.org/10.30743/mes.v2i1.110

Chambers. (2008). Teaching Mathematics. London: SAGE Publications Ltd.

Chee \& Wong. (2003). Teaching and Learning with Technology: An Asia-Pacific Perspective. Singapore: Prentice Hall.

Darminto, B. P. (2011). Efektifitas pembelajaran model Allan G. Bluman dalam peningkatan pemahaman konsep matematika mahasiswa. Cakrawala Pendidikan, 30 (2), 326-340. https://doi.org/10.21831/cp.v0i2.4240

Ompussunggu, D. V. K (2014). Peningkatan kemampuan pemahaman matematik dan sikap positif terhadap matematika siswa SMP Nasrani 2 Medan melalui pendekatan Problem Posing. Jurnal Saintech, 6(4), 93-105

Fumiyuki, T. (2000). An Ideal Use of Computer in High School Mathematics Education. In O. Toshio (Ed.), Mathematics Education in Japan. Tokyo: Japan Society of Mathematics Education

Richi, N \& Mukhtar. (2017). Perbedaan kemampuan pemahaman konsep matematika siswa menggunakan model pembelajaran Problem Based Learning dengan model pembelajaran Discovery Learning berbantuan Cabri 3d di Kelas VII SMP Negeri 27 Medan. Jurnal Inspiratif, 3(1), 86-95. https://doi.org/10.24114/jpmi.v3i1.8886

Safitri, M. (2017). Implementasi model pembelajaran kooperatif Tipe Teams Games Tournament (TGT) untuk melatih pemahaman konsep siswa. UNION: Jurnal IImiah Pendidikan Matematik, 5 (3), 237-244

Setiawan, W. (2005). Model Pembelajaran Berbasis Komputer dalam Upaya Meningkatkan Pemahaman Konsep, KBK, dan Sikap Positif Siswa SMA. Makalah pada Seminar Nasional Pendidikan IPA II 22-23 Juli 2005, Bandung. 